\title{
On the salt transport in the Cananéia sea during a spring tide experiment
}

\author{
Luiz Bruner de Miranda \& Belmiro Mendes de Castro Filho \\ Instituto Oceanográfico da Universidade de São Paulo \\ (Caixa Postal 66149, 05315-970, São Paulo, SP, Brasil)
}

- Abstract: Observations of the velocity, salinity, water depths and tides in the southern region of the Cananéia Sea were sampled at an anchored station during two complete tidal cycles. The measurements were made during spring tides on 5-6 December, 1991. The observed non-tidal current profile for this weakly stratified tidal channel is found to be in close agreement with the results of a simple steady state unidimensional analytical model of a well-mixed estuary. This comparison indicates that the primary driving mechanisms are the longitudinal salinity gradient and the fresh water discharge. The contribution to the advective salt transport is dominated by the freshwater discharge through the down-stream non-tidal flow and the up-stream dispersive term due to Stokes wave transport. This dispersive term is almost one order of magnitude smaller than the down-stream non-tidal transport induced by the fresh water discharge. Tidal correlation, acting as a counter-dispersion term, and the steady shear dispersion term are two orders of magnitude smaller than the down-stream salt transport. The remaining dispersive terms, which are dependent on the deviations from the mean depth, are smaller than either of these terms by one order of magnitude. The computed total salt transport per unit width of a section perpendicular to the mean flow was in close agreement (within $12 \%$ ) with the sum of the individual advective and dispersive terms. On the assumption that the tidal channel sampled is laterally homogeneous, an imbalance of the salt budget across the section was observed.

- Resumo: Observacões de velocidade, de salinidade, de profundidade e de maré na região sul do Mar de Cananéia foram realizadas numa estação fixa durante dois ciclos completos de maré. Essas medidas foram feitas durante maré de sizígia, no período de 5 a 6 de dezembro de 1991. A exame comparativo do perfil estacionário de velocidade desse sistema fracamente estratificado, indicou boa concordância com os resultados de um modelo analítico unidimensional de um estuário ideal verticalmente homogêneo. Dessa comparação, foi possível concluir que as principais forças geradoras desse movimento são o gradiente longitudinal de densidade e a descarga de água doce. A contribuição para o transporte advectivo de sal é dominado pela descarga total de água doce e pelo termo dispersivo, gerado pela propagação da onda de maré no canal estuarino (transporte de Stokes). Esse termo dispersivo é quase uma ordem de grandeza menor do que o termo associado à descarga estacionária de água doce. O termo de correlação da maré, que atua no sentido contrário aos termos dispersivos e o termo dispersivo gerado pelo cisalhamento da circulação gravitacional, são cerca de duas ordens de grandeza menores do que a parcela advectiva estacionária que atua estuário abaixo. Os termos dispersivos remanescentes e que dependem da amplitude da maré, são uma ordem de grandeza menores do que o valor estimado para o termo gerado pela circulação gravitacional. O transporte total de sal, por unidade de largura da seção transversal, integrado diretamente é concordante com o valor obtido pela somatoria de todos os termos advectivos e dispersivos, com um desvio inferior a $12 \%$. Na hipótese de que o canal estuarino amostrado é lateralmente homogêneo, observou-se que o transporte de sal não estava em balanço.

- Descriptors: Estuaries, Salt transport, Salt balance, Advection, Dispersion, Non-tidal profiles, Experimental and theoretical results.

- Descritores: Estuários, Transporte de sal, Balanço de sal, Advecção, Dispersão, Perfil estacionário, Resultados teóricos e experimentais.

\section{Introduction}

An estuary is defined as a semi-enclosed coastal body of water which has a free connection with the open sea and

Contr. no. 801 do Inst. oceanogr. da Usp. within which sea water is measurably diluted with fresh water derived from land drainage (Pritchard, 1967). This definition implies that the salt may be used as a natural tracer for estuarine waters. Its flux and transport due to advection and turbulent diffusion may be used to predict the main physical mechanisms responsible for the transport of other soluble conservative substances. 
The fresh water discharge and the barotropic and baroclinic components of the gradient pressure force due to tides and the longitudinal salinity (density), respectively, are the main forcing mechanisms which drive the circulation and provide the turbulent energy for the mixing process in a tidal channel.

At the simplest level, an estuary or a tidal channel may be considered as a "black box" which pumps salt upstream against the mean river flow (Hunkins, 1981). Among the processes that produce mixing, longitudinal turbulent diffusion plays only a minor part, and the overall landward mixing is better termed dispersion rather than diffusion (Fischer, 1976; Hunkins, op. cit.). Consequently, the circulation component due to the river discharge drives the advective seaward salt transport and the dispersion produced primarily by the effects of tides, gravitational circulation and winds is responsible for the landward salt transport.

The Lagoon-Estuary System of Cananéia-Iguape is a $75 \mathrm{~km}$ long complex coastal plain estuarine system, composed of several channels between the Cananeia, Cardoso and Comprida Islands in the southern region of the São Paulo State (Fig. 1). This system has three openings to the sea: the main mouth named Barra de Cananéia which is a complex shallow water entrance, the Icapara Bar which is the northern mouth of the system and a choked opening at Ararapira to the south.

The Cananéia Sea is a branch of the southern entrance of the estuarine system. It is a shallow weakly stratified tidal channel driven by semi-diurnal tides (Miyao, 1977; Miyao et al. 1986 and Miyao \& Harari, 1989). This region has been classified as a weakly partially mixed (Type 2a) estuary (Miranda et al. 1995; Bonetti Filho, 1995) and due to the small ratio of tidal amplitude/mean water depth it is an ebb-dominant system. The influence of the wind stress over the water body is of minor importance as regards the stationary circulation, as demonstrated by Miranda (1990) based on simulations of the stationary vertical velocity profiles with a bidimensional analytical model.

The data analysed in this paper were sampled at the spring tide during two tidal cycles $(25 \mathrm{~h})$ on 5-6 December, 1991. Its objective is to investigate the main driving forces of the non- tidal circulation and to calculate the advective and dispersive contributors to the salt transport. The salt transport is computed per unit width of a section perpendicular to the channel passing through the fixed station $F$, located near the mouth of the main entrance of the Cananéia Sea (Fig. 1).



Fig. 1. Southern region of the Cananéia-Iguape Lagoon-Estuarine system. Observations were made at station $F$, northeast of Ponta do Arrozal. 


\section{Current and salinity observations}

Hydrographic properties, current profiles and water depth were sampled during three tidal cycles at one anchored station located NE of Ponta do Arrozal, approximately in the middle of the channel (Fig. 1). Simultaneously the tidal height was recorded on a standard tide gauge A. OTT model, installed at the Cananéia Field Rescarch Station of the Occanographic Institute of the University of São Paulo (Fig. 1). Mcasurements were made at approximately hourly intervals and a complete data set down the water column was obtained in 20-30 minutes. Following the standard procedure, the along channel velocity component ( $\mathrm{v}$ - component) and the salinity profiles were combined into an almost simultaneous set of hourly measurements. The Oy axis for computation of the along channel component was oriented northward, and a detailed description of the equipment, data collection and edition was drawn up by Miranda et al. (1995).

The sampling depth of each measurement was further reduced to the non-dimensional depth $[\mathrm{Z}=\mathrm{z} / \mathrm{h}(\mathrm{t})]$, taking into account the local water depth $[h(t)]$, to minimize the sampling water depth variations during the tidal cycle (Kjerfve, 1975). Down the water column, the measurements were interpolated from surface to bottom in depth intervals of $Z / 10$. In the numerical integration the surface and the bottom values were assigned one-half of the weight of the others, when integrated over depth. In the time sequence, two tidal cycles were considered $(25 \mathrm{~h})$ and to the first and the last values of the time series were assigned one-half of the weight of the others, when numerical integration was made over time.

\section{Non-tidal current and salinity profiles}

Profiles of the non-tidal currents and the corresponding salinity results according to Miranda et al. (1995) are shown in Figure 2a, b. The steady-state profile of the along channel component, $\langle\mathrm{v}\rangle$ indicates an almost net seaward flow and a weak flow reverse near the bottom, which is typical for a weakly stratified estuary. The weak residual seaward current is estimated at $\mathrm{v}_{\mathrm{a}}=-2.6$ $\mathrm{cms}^{-1}$. The associated non-tidal salinity profile (Fig. $2 b$ ), shows a weak salinity stratification down the water column varying around its mean depth value $\left(\mathrm{S}_{\mathrm{a}}=32.5 \%\right.$ o $)$.

In order to obtain a further insight into the driving forces of the steady-state circulation based on the experimental results (Fig. 2), let us consider the analytical vertical profile of an idealized unidimensional well-mixed estuary, which is given (Officer, 1977) by:

$$
\begin{gathered}
V(z)=\left[\frac{g \beta S_{X} h^{3}}{48 A_{z}}\right]\left(1-9 Z^{2}+8 z^{3}\right)+\frac{3}{2} v_{f}\left(1-z^{2}\right) \\
+\frac{\tau_{W x} h}{4 \rho A_{z}}\left(1-4 Z+3 Z^{2}\right)
\end{gathered}
$$

where $\rho \approx 10^{3} \mathrm{~kg} \mathrm{~m}^{-3}$ is the density, $\mathrm{g}=9.8 \mathrm{~m} \mathrm{~s}^{-1}$ the acceleration due to gravity, $\beta \approx 7.10^{-4}$ the coefficient of saline contraction and $S_{x}$ the longitudinal salinity gradiente. $A_{z}, \tau_{w x}$ and $h$ are the kinematic coefficient of eddy viscosity, the longitudinal wind stress and depth, respectively. $v f$ is the velocity component generated by the fresh water discharge, which in a first approximation is assumed to be equal to the residual velocity $\left(\mathrm{v}_{\mathrm{f}}=\mathrm{v}_{\mathrm{a}}=-2.6 \mathrm{~cm} \mathrm{~s}^{-1}\right)$.

This theoretical result (eq. 1) indicates that the non-tidal velocity profile in a well-mixed estuary has three components driven by the following forcing mechanisms: the baroclinic gradient pressure force due to the longitudinal salinity gradient $\left(S_{\mathbf{x}}\right)$, the fresh water discharge $\left(\mathrm{Q}_{\mathrm{f}}\right)$ and the wind stress $\left(\tau_{\mathrm{wx}}\right)$.

The coefficients of the polynomials in $\mathrm{Z}$ of equation 1 , which represents the current velocity at the surface $(\mathrm{Z}=0)$, may have their orders of magnitude estimated. According to experimental results of the longitudinal salinity variation in the Cananćia Sea (Miyao et al., 1986), we may estimate $S_{x}=-4.3 \times 10^{-3} \% o \mathrm{~m}^{-1}$. Taking from the literature $A_{z} \approx 2 \times 10^{-3} \mathrm{~m}^{2} \mathrm{~s}^{-1}$, assuming low mean wind speeds with intensities of $5 \mathrm{~m} \mathrm{~s}^{-1}$, and the mean value for the depth as $5.8 \mathrm{~m}$, it follows that:

$O\left(\frac{g \beta S_{x} h^{3}}{48 A_{z}}\right) \approx-6 \cdot 10^{-2} \mathrm{~ms}^{-1}$

$O\left(\frac{3}{2} v_{f}\right) \approx-4 \cdot 10^{-2} m s^{-1}$

$O\left(\frac{\tau_{w x} h}{4 \rho A_{z}}\right) \approx 4 \cdot 10^{-3} \mathrm{~ms}^{-1}$.

These orders of magnitude indicate that the velocity component driven by the wind stress is one tenth smaller than the others.

Using these orders of magnitude we may estimate the non-tidal current profile for the region studied. The theoretical profile, shown in Figure 3, is in close agreement with the experimental results plotted comparatively in this figure. Consequently, the observed non-tidal current profile is mainly driven by the longitudinal salinity gradient and the fresh water discharge. For this estuarine system, a similar result has also been reported by Miranda (1990) on the basis of a steady two-dimensional analytical model. 

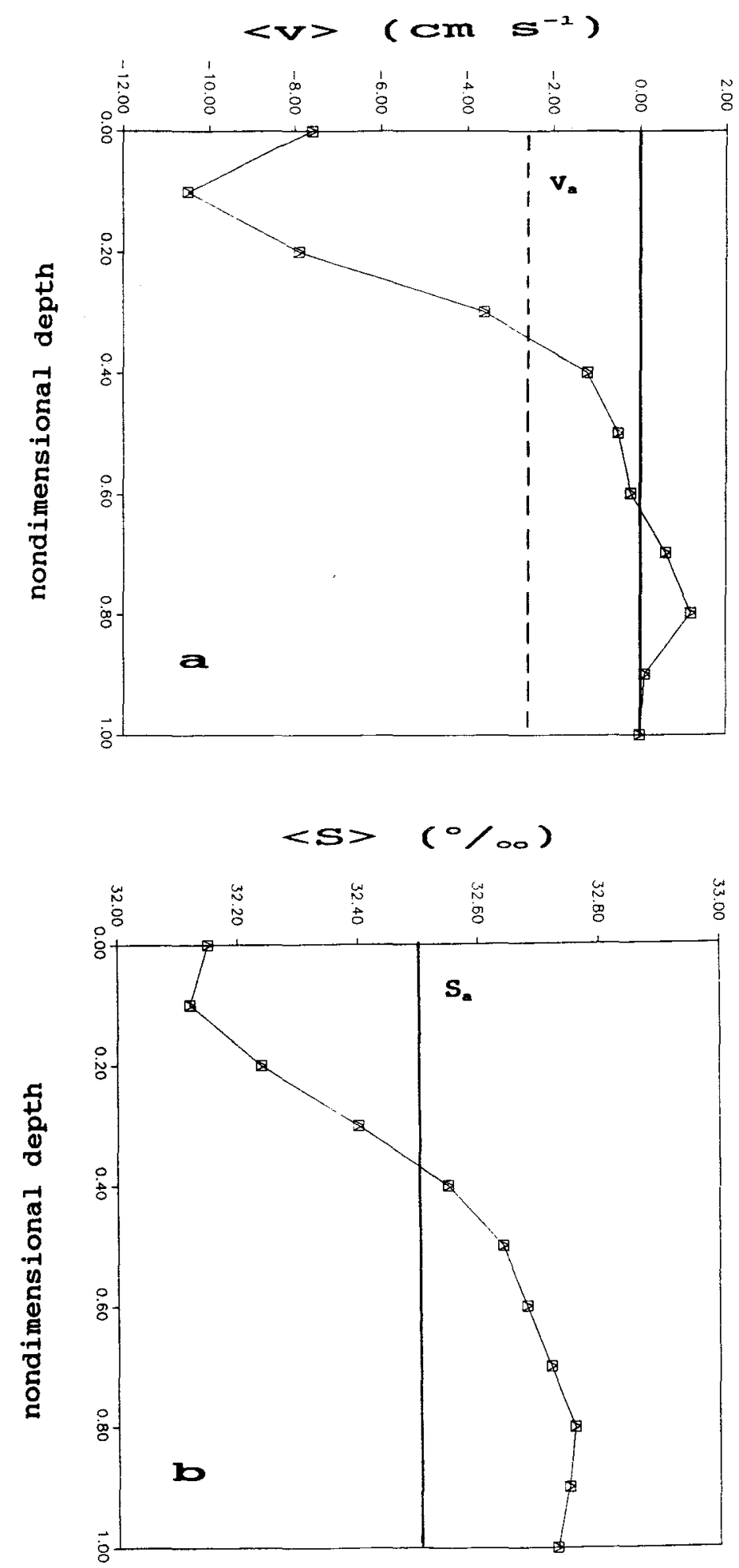

Fig. 2. Non-tidal v-velocity component (a) and salinity (b) profiles at station F on 5-6 of December 1991.

(Adapted from Miranda et al., 1995). 


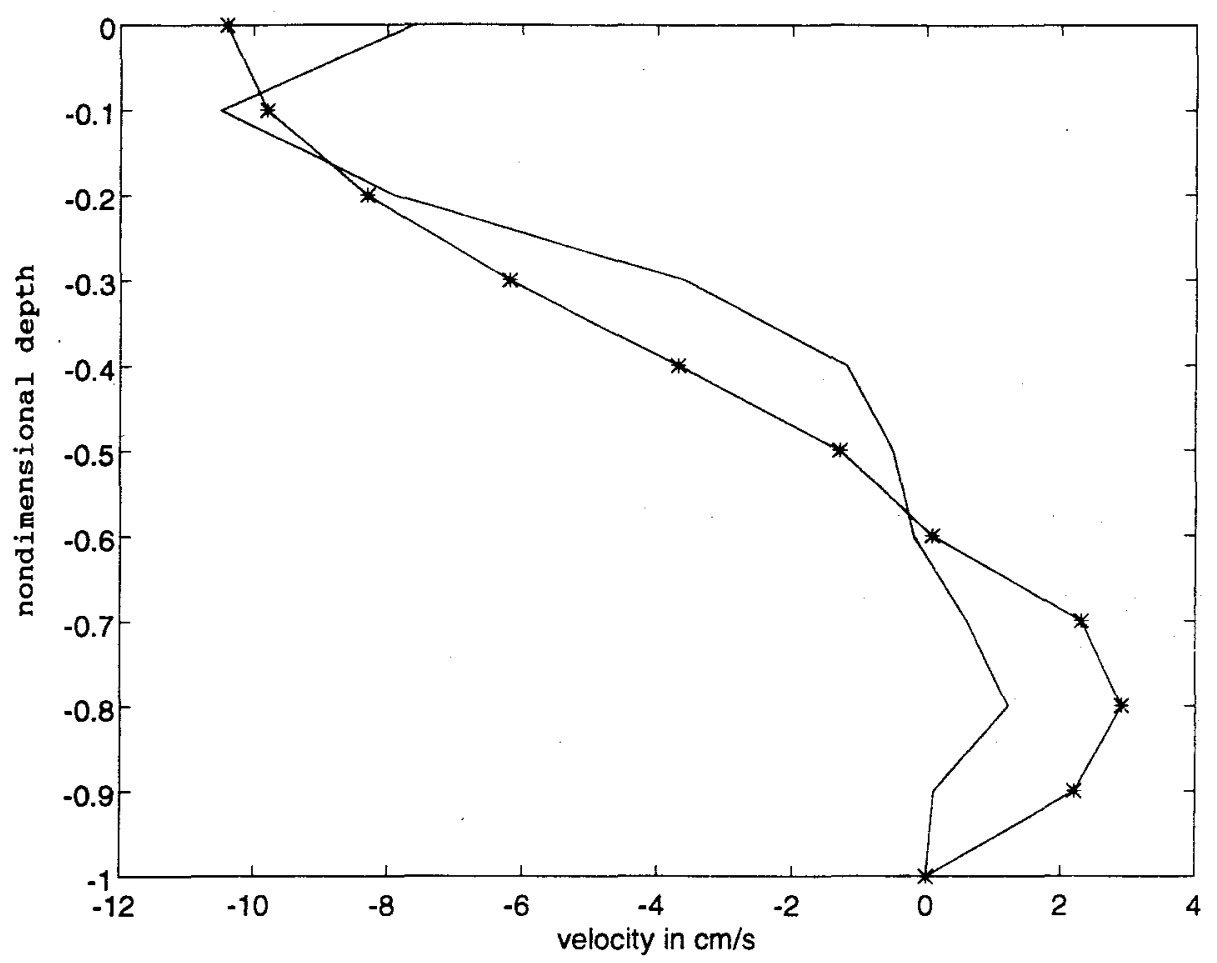

Fig. 3. Non-tidal vertical velocity profile based on the observations (solid line), in comparison with the simulation based on a unidimensional steady state analytical model for an idealized well-mixed estuary $\left({ }^{*}\right)$.

\section{Salt transport calculations}

The instantaneous advective mass transport of salt per unit width of a section, perpendicular to the longitudinal flow of the estuarine channel, is equal to:

$M_{S}=\int_{0}^{h} \rho v S d z=\overline{\rho v S} . h$.

where $v$ and $S$ are the longitudinal velocity component and salinity, respectively. The upper bar denote averaging over the total depth of the water column, h. In the International System of Units (SI), the salt transport, $\mathbf{M}_{\mathbf{S}}$, is given in $\mathrm{kg} \mathrm{m}^{-1} \mathrm{~s}^{-1}$.

The non-tidal salt transport (TS), over one or more complete tidal cycles $(T)$, is given by,

$$
T_{S}=\frac{1}{T} \int_{0}^{T} M_{S} d t=\overline{\boldsymbol{p}}\langle\overline{v S h}\rangle
$$

where the mean density $\bar{\rho}$ was assumed to be constant and the angle brackets denote the time average over a tidal cycle. The time interval $\mathrm{T}$ is a multiple integer of the tidal period.
If only one of the variables of the second member of the equation (6), such as the v-velocity component is considered, its time-average of depth-average (residual current) is formally given by,

$\langle\bar{v}\rangle=\frac{1}{T} \int_{0}^{T}\left[\frac{1}{h} \int_{0}^{h} v(x, z, t) d z\right] d t=\frac{1}{T} \int_{0}^{h} \bar{v} d t$,

and a similar equation may be applied for the time-average of the depth-average of the salinity .

In the case of a tidal flow, only a part of the salt transport is described by the product of the tidal and depth averages of the v-velocity component and salinity. As has been shown, various correlations can generally be identified with a particular physical process (Bowden, 1963; Dyer, 1973; Fischer, 1976; Hunkins, 1981, Kjerfve, 1986). These correlations may be obtained by the decomposition of the instantaneous velocity and salinity profiles into four components and the water depth into two components. For a laterally homogeneous estuary or when the salt mass transport is computed per unit width of a section perpendicular to the mean flow at time $t$, these profiles may be written as: 


$$
\begin{aligned}
v(x, z, t)= & v_{a}(x)+v_{t}(x, t)+v_{s}(x, z) \\
& +v^{\prime}(x, z, t),
\end{aligned}
$$

$$
\begin{aligned}
S(x, z, t)= & S_{a}(x)+S_{t}(x, t)+S_{s}(x, z) \\
& +S^{\prime}(x, z, t),
\end{aligned}
$$

where $v_{a}=\langle\bar{v}\rangle$ is calculated with equation (7) and $\mathrm{S}_{\mathbf{a}}=\langle\overline{\mathrm{s}}\rangle$ using a similar expression.

The second and third terms of the equations (8) and (9) $v_{t}=v_{t}(x, t)$ and $v_{s}=v_{s}(x, z)$ and the corresponding terms of salinity $\left[S_{t}(x, t)\right.$ and $\left.s_{s}(x, z)\right]$ have been introduced into the decomposition to take into account the tidal (barotropic) and the steady-state components of the gravitational circulation (baroclinic), respectively, and are defined by

$v_{t}=\bar{v}-v_{a}$

$S_{t}=\bar{s}-S_{a}$,

$v_{s}=\langle v\rangle-v_{a}$,

$s_{s}=\langle S\rangle-S_{a}$.

Finally, the terms $v^{\prime}(x, z, t)$ and $s^{\prime}(x, z, t)$ of equations (8) and (9) are the remainders, when the various averages are subtracted from the instantaneous velocity (v) and salinity (S),

$$
v^{\prime}=v-v_{a}-v_{t}-v_{s}
$$

and

$$
s^{\prime}=s-S_{a}-S_{t}-s_{s}
$$

These terms are called deviation components (Hunkins, 1981).
The local depth, $h(x, t)$ at the anchored station varies with the tidal height and may be decomposed into two components,

$$
h(x, t)=h_{a}+h_{t}(x, t),
$$

where $h_{a}=\langle h\rangle$ is the time-average water depth and $h_{t}(x, t)$ is the tidal height.

By introducing equations (8), (9) and (16) into equation (6), the advective salt transport under steady-state conditions may be decomposed into 32 terms. By virtue of the definitions many of these terms vanish or may be neglected upon forming averages over depth and time (Bowden, 1963; Dyer, 1973; Fischer, 1976),

$$
\left\langle v_{t}\right\rangle=\bar{v}_{s}=\left\langle\overline{v^{\prime}}\right\rangle=\overline{v^{\prime}}=0,
$$

and the cross product of the form $\mathrm{va}_{\mathrm{a}} \mathrm{S}_{\mathrm{t}}$, etc.

Disregarding other terms for which there is no physical reason to expect correlations between steady, tidal and deviation components, this leaves seven terms and the total transport of salinity, per unit width, during a tidal cycle is given by,

$$
\begin{aligned}
& T_{s}=\bar{p}\left[\left[v_{a} h_{a}+\left\langle h_{t} v_{t}\right\rangle\right] S_{a}+h_{a}\left\langle v_{t} S_{t}\right\rangle+h_{a} \overline{V_{s} s_{s}}\right. \\
& \begin{array}{llll}
\text { a } & b & c & d
\end{array} \\
& \left.+h_{a}\left\langle\bar{v} \bar{s}^{\prime}\right\rangle+\left\langle v_{t} S_{t} h_{t}\right\rangle+v_{a}\left\langle S_{t} h_{t}\right\rangle\right] \text {. } \\
& \text { e } \quad \mathrm{g}
\end{aligned}
$$

The terms (a) to (g), on the right-hand side of the equation (17), have been related to certain physical processes and the following associated physical mechanisms (Bowden, 1963; Dyer, 1973 and 1978; Fischer, 1976; Hunkins, 1981; Kjerfve, 1986): fresh water discharge (a), Stokes drift or progressive tidal wave transport (b), topographic trapping (c), gravitational circulation, bathymetric tidal pumping and steady wind effect (d), tidal shear and unsteady wind effect (e), and tide dispersion via tripple correlation (f). The last term (g), corresponds to the net advection of the cross correlation between tide and salt. 
This method has been applied to the study of the variation of the relative contribution of these individual terms of salt transport to systems with different degrees of salt stratification, and thesc have been reported in several studics (Bowden, op. cit.; Dyer, 1978; Fischer et al. 1979; Hunkins, 1981, and others). Variations along the Tees Estuary in the relative contribution of the individual salt transport terms to the net upstream transport of salt, during neap and spring tides, have been studied by Lewis \& Lewis (1983).

Equations (6) and (17) are distinct mathematical expressions of the same physical quantity. Comparison of the results for the net salt transport, computed with these equations, will be used as a check on the computational procedure and if the terms disregarded are, in fact, small.

\section{Results and discussion}

Numerical integration in space (depth) and time of edited raw data was used to calculate $\bar{v}, \bar{S},\langle\mathrm{v}\rangle,\langle\mathrm{S}\rangle$, and the steady values $v_{a}, S_{a}$ and $h_{a}$. Using definitions given in equations (10) to (13) the various components (tidal, steady and the deviation component) of the instantaneous values of the v-component and salinity (equations 8 and 9) were obtained. Equation (16) was used to compute the tidal oscillation $h_{t}$, superimposed on the mean water depth, $<\mathrm{h}>$.

The mean value of the along channel velocity component, $\mathrm{v}_{\mathrm{a}}$, is equal to $-2.6 \mathrm{~cm} \mathrm{~s}^{-1}$. The negative sign indicates a net seaward flow and is consistent with the expected non-tidal velocity component, induced by the fresh water discharge into the system. Due to the lack of knowledge of the discharge of the rivers which empty into the system, this mean value will be used as a first approximation to estimate this term of the seaward advective salt transport (a). The corresponding mean salinity value, $S_{a}$, is equal to $32.5 \%$ and the mean water depth $\left(h_{a}\right)$ is estimated at $5.8 \mathrm{~m}$. These mean results are summarized in Table 1.

The numerical results of equations (6) and (17) for the estimation of the net advective salt transport and its dispersive terms were calculated using a constant mean density value $\left(\bar{\rho}=10^{3} \mathrm{~kg} \mathrm{~m}^{-3}\right)$. The advective and dispersive terms obtained using these equations are presented in Table 2.

The predominant contribution to the salt transport are terms (a) and (b) with estimated values of -5.1 and $0.8 \mathrm{~kg} \mathrm{~m}^{-1} \mathrm{~s}^{-1}$, respectively (Table 2 ). These terms represent salt transport due to the fresh water discharge. Term (a) is the highest and gives a seaward contribution due to the non-tidal velocity component induced by the river discharge. The landward term (b) is due to the Stokes velocity, which is associated with a finite-amplitude tidal-wave propagating up and down the tidal channel.

The terms which represent the tidal correlation (c) and the steady shear dispersion (d), were estimated at -0.10 $\mathrm{kg} \mathrm{m}^{-1} \mathrm{~s}^{-1}$ and $0.10 \mathrm{~kg} \mathrm{~m}^{-1} \mathrm{~s}^{-1}$, respectively, and are almost one order of magnitude smaller than the Stokes wave drift term (Table 2). Being a negative value, the salt transport associated with the tidal correlation term (c) is directed seaward and does not disperse salt in the estuary, acting as a counter-dispersive term.

For an idealized well-mixed estuary, maximum salinity would be reached at the end of the flood tide and a phase difference of $90^{\circ}$ would be expected between $v_{t}$ and $S_{t}$, with no net contribution to the salt transport. During this period of observation the southern region of the Cananéia Sea was a weakly stratified (Type 2a) estuary, forced by tides with semi-diurnal inequalities, with a flood time interval greater than the corresponding ebb (Miranda et al., 1995). Also, it was observed that the salinity maxima lag behind the flood current maxima and the strongest ebbing currents lead the salinity minima. These results, associated with the topographical trapping, may explain the occurrence of the counter-dispersion of the tidal correlation term (c), for which the tidal salinity must lag behind the tidal current by a phase angle greater than $90^{\circ}$ (time lag greater than $3 \mathrm{~h}$ ). This time lag, required to make (c) a negative term, is confirmed by comparing Figures $4 \mathrm{a}$ and $4 \mathrm{~b}$, which show the mean tidal variation of the along channel current component $\left(\mathrm{v}_{\mathrm{t}}\right)$ and the corresponding salinity variation $\left(S_{1}\right)$, respectively.

Table 1. Non-tidal mean values of the v-component $\left(\mathrm{V}_{\mathrm{a}}\right)$, salinity $\left(\mathrm{S}_{\mathrm{a}}\right)$ and water depth

$(\mathrm{ha})$, based on a two tidal cycle $(25 \mathrm{~h})$ time interval

\begin{tabular}{|c|c|c|}
\hline$v_{a}\left(\mathrm{~cm} \mathrm{~s}^{-1}\right)$ & $\mathrm{S}_{\mathrm{a}}(\% / 0)$ & $\mathrm{h}_{\mathrm{a}}(\mathrm{m})$ \\
\hline-2.6 & 32.5 & 5.8 \\
\hline
\end{tabular}


Table 2. Salt transport components based on a two tidal cycle (25 hours) time interval and analytical expressions

Estimated values, in $\mathrm{kg} \mathrm{m}^{-1} \mathrm{~s}^{-1}$

\begin{tabular}{|c|c|c|}
\hline $\mathbf{a}$ & -5.10 & $\bar{\rho} v_{a} h_{a} S_{a}$ \\
\hline b & 0.80 & $\bar{\rho}<\mathrm{h}_{\mathrm{t}} \mathrm{V}_{\mathrm{t}}>\mathrm{S}_{\mathrm{a}}$ \\
\hline c & -0.10 & $\bar{\rho} h_{a}<V_{t} S_{t}>$ \\
\hline d & 0.10 & $\bar{\rho} h_{a} \bar{v}_{s} s_{s}$ \\
\hline e & 0.01 & $\bar{p} h_{a}\left\langle\overline{v^{\prime} s^{\prime}}\right\rangle$ \\
\hline$f$ & 0.03 & $\bar{\rho}<v_{t} S_{t} h_{t}>$ \\
\hline$g$ & 0.04 & $\left.\bar{\rho} V_{a}<S_{t} h_{t}\right\rangle$ \\
\hline$\Sigma=a+b+c+d+e+f+g$ & -4.22 & \\
\hline Equation 6 & -4.70 & \\
\hline
\end{tabular}

Figure 4a shows the tidal current $\left(v_{t}\right)$ to be almost sinusoidal and superimposed upon a weak residual current $\left(v_{a}\right)$ which is directed seaward. The corresponding salinity variation $\left(\mathrm{S}_{\mathrm{t}}\right)$, shown in Figure $4 \mathrm{~b}$, is asymmetrical about the current reversal and, although there is a large time lag $(>3 \mathrm{~h}$ ) between these quantities, the strong influence of the advective longitudinal salt transport, driven by the barotropic influence of tides is clear. Time intervals of the positive (seaward) and negative (landward) tidal correlation salt transport term (c), during the mean tidal period, is also shown in Figure 4b; as described above, the associated net salt transport is a counter-dispersion term (directed up estuary).

Tidal correlation, acting as a counter-dispersion term, had been previously observed in the highly stratified Hudson Estuary (Hunkins, 1981), and in a station far up the Tees Estuary (Lewis \& Lewis, 1983) where there was a very weak salinity stratification.

The steady shear term, due to the vertical gravitational acceleration as indicated by term (d), is directed landward and its value has been estimated at $0.10 \mathrm{~kg} \mathrm{~m}^{-1} \mathrm{~s}^{-1}$ (the same magnitude as the tidal correlation term, but in the opposite direction). This result is in agreement with the weak salinity stratification of this tidal channel. The profiles of the nontidal $v_{s}$ and $s_{s}$, used to calculate this term (Fig. 5a,b), have predominantly the same sign down the water column and this clearly indicates the dispersive nature of this term. Figure $5 \mathrm{~b}$ shows the water depth intervals with positive (landward) salt flux due the correlation between the tidal oscillations in velocity and salinity.

In the partially mixed estuary type with pronounced gravitational circulation like the Hudson Estuary, term (d) is one of the largest contributors to the salt dispersion and increases in magnitude during the high-flow period (Hunkins, op. cit).

The remaining terms (e), (f) and (g) are dispersive and marginally small (Table 2). Term (e), defined as the oscillatory dispersion term, may be generated by unsteady wind effect and tidal shear. The salt dispersion term ( $f$ ) corresponds to the tidal dispersion via triple correlation; since it is a function of the tidal amplitude its small value $\left(0.03 \mathrm{~kg} \mathrm{~m}^{-1} \mathrm{~s}^{-1}\right)$ may be due to the moderate amplitude of the forcing tidal wave.

Finally, the last dispersive term (g) also has a small value $\left(0.04 \mathrm{~kg} \mathrm{~m}^{-1} \mathrm{~s}^{-1}\right)$ and corresponds to the net advection of the cross-correlation between tide and salt (Table 2). As with term (f), we should expect a small value for this term, since it is dependent on the tidal amplitude. 

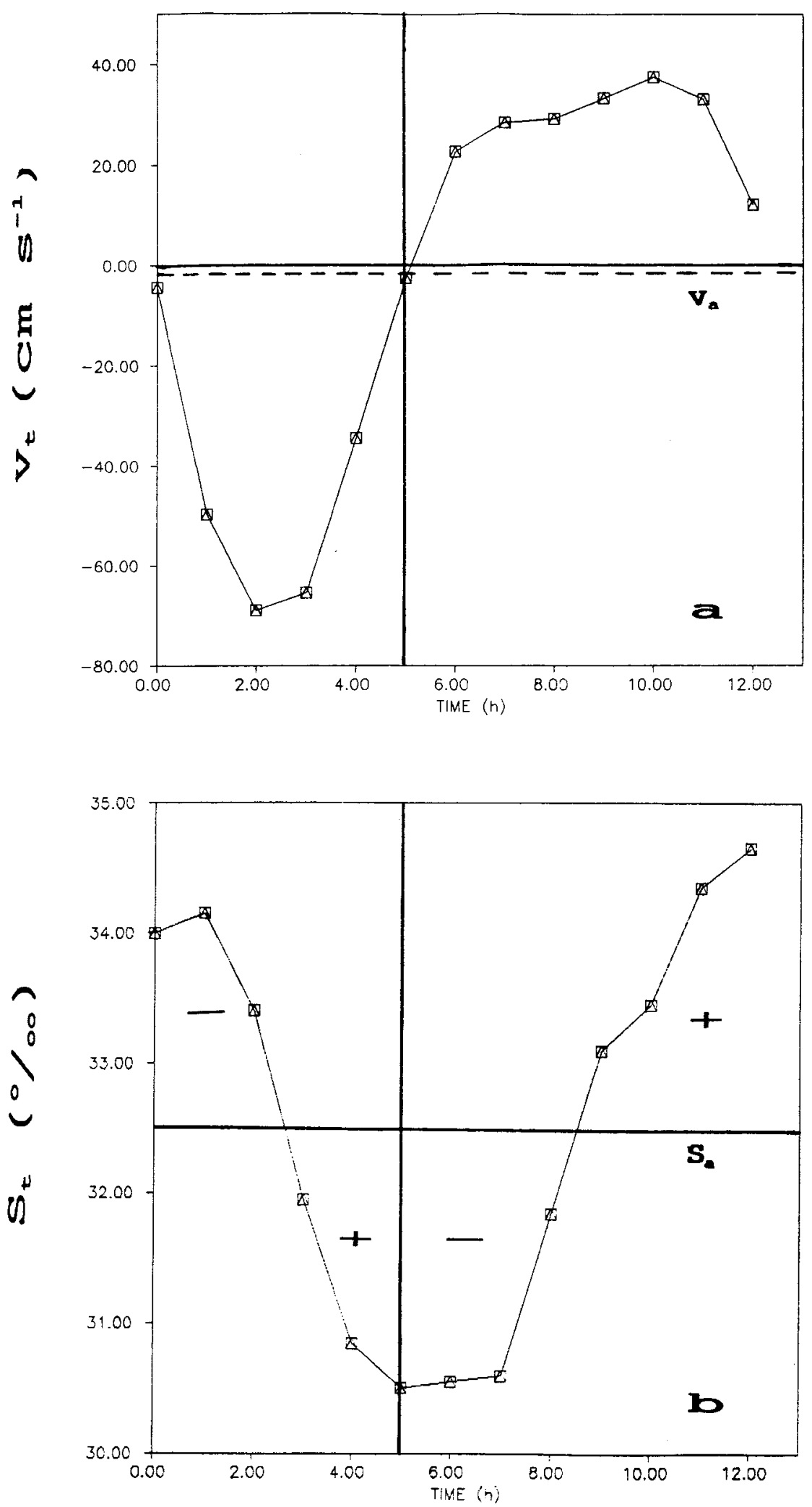

Fig. 4. Tidal variation of $v_{t}(a)$ and $S_{t}(b)$, representing mean values for two tidal cycles. Time intervals of positive (landward) and negative (seaward) tidal correlation transport are shown in the lower figure. 

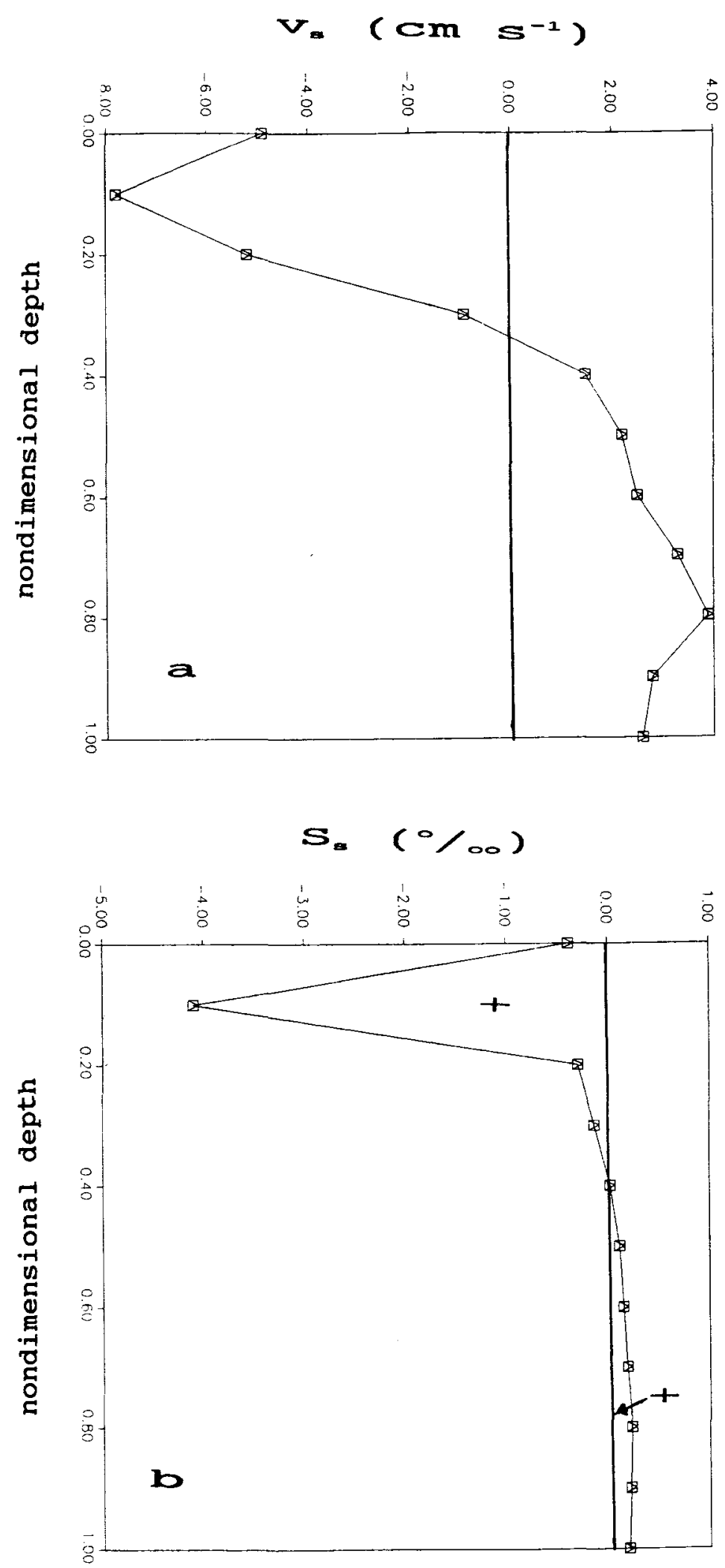

Fig. 5. Non-tidal profiles of $v_{s}(a)$ and $S_{s}$ (b). Depth intervals of positive (landward) salt transport, due to the gravitational circulation, are shown in the lower figure. 
As a check on the use of equation (17), originally with 32 terms but simplified to only seven, a calculation was made using equation (6) and the resulting values are compared in the last two rows of Table 2 . There was agreement between the calculations within $12 \%$, confirming that the various terms omitted to obtain equation (17) were of negligible effect. This result indicates an imbalance in the net advective salt budget and during this observation period the Cananeia Sea was therefore exporting salt. It should be made clear that this imbalance is due not only to the hypothesis that the channel investigated is laterally homogeneous, but mainly because the data sampling was undertaken in the southern region of a complex branching system.

\section{Acknowledgements}

Preparation of this paper was supported by Conselho Nacional de Desenvolvimento Científico e Tecnológico-CNPq (Proc. 301014/79-5 and Proc. 303877/86-3)

\section{References}

Boncti Filho, J. 1995. Transporte de sedimentos por suspensão nas proximidades da Barra de Cananéia. Dissertação de mestrado. Universidade de São Paulo, Instituto Oceanográfico. v.I (Texto) 115 p. e v.II (Tabelas e Figuras) 146 p.

Bowden, K. F. 1963. The mixing processes in a tidal estuary. Int. Int. J. Air Pollut., (7):343-356.

Dyer, K. R. 1973. Estuarics: A physical introduction. New York, John Wiley \& Sons. 140 p.

Dyer, K. R. 1978. The balance of suspended sediment in the Gironde and Thames Estuaries. In: Kjerfve, B. ed. Estuarine Transport Processes. Columbia, University of South Carolina Press. p. 135-145.

Fischer, H. B. 1976. Mixing and dispersion in estuaries. Annual review of fluid mechanics. Annual Reviews, (8):107-133.

Fischer, H. B.; List, E. J.; Koh, R. C. Y.; Imberger, J. \& Brooks, N. H. 1979. Mixing in inland and coastal waters. New York, Academic Press. 483 p.
Hunkins, K. 1981. Salt dispersion in the Hudson Estuary. J. phys. Oceanogr., 11(5):729-738.

Kjerfve, B. 1975. Velocity averaging in estuaries characterized by a large tidal range to depth ratio. Estuar. coast. mar. Sci., (3):311-323.

Kjerfve, B. 1986. Circulation and salt flux in a well mixed estuary. In: Kreeks, J. van de ed. Physics of Shallow Estuaries and Bays. New York, Spring Verlag. p. 22-29.

Lewis, R. E. \& Lewis J. O. 1983. The principal factors contributing to the flux of salt in a narrow, partially stratified estuary. Estuar. coast. mar. Sci., (16):599-626.

Miranda, L. B. 1990. Sistemas estuarinos de planície costeira: estrutura dinâmica, processos de mistura e aplicações. In: II SIMPÓSIO DE ECOSSISTEMAS DA COSTA SUL E SUDESTE BRASILEIRA, ESTRUTURA, FUNÇĀO E MANEJO. 2. Águas de Lindóia, 1987. São Paulo, ACIESP, 71(2):1-46.

Miranda, L. B. de; Mesquita, A. R. de \& França, C. A. S. 1995. Estudo da circulação e do processo de mistura no extremo sul do Mar de Cananéia. Condições de dezembro de 1991. Bolm Inst. oceanogr., S Paulo, 43(2):153-164.

Miyao, S. Y. 1977. Contribuição ao estudo da Oceanografia Física da região de Cananéia (lat. $25^{\circ} \mathrm{S}$; long. $048^{\circ} \mathrm{W}$ ). Dissertação de mestrado. Universidade de São Paulo, Instituto Oceanográfico. 87 p.

Miyao, S. Y.; Nishihara, L. \& Sarti C. C. 1986. Características físicas e químicas do sistema estuarino-lagunar de Cananéia-Iguape. Bolm Inst. oceanogr., S Paulo, 34(único):23-36.

Miyao, S. Y. \& Harari, J. 1989. Estudo preliminar da maré e das correntes de maré na regiāo estuarina de Cananéia $\left(25^{\circ} \mathrm{S}-048^{\circ} \mathrm{W}\right)$. Bolm Inst. oceanogr., S Paulo, 37(2):107-123.

Officer, C. B. 1977. Longitudinal circulation and mixing relations in estuaries. In: Estuaries, geophysics, and the environment. Washington, D.C., National Academy of Sciences. p. 13-21.

Pritchard, D. W. 1967. What is an estuary: physical view-point. In: Lauff, G. H. ed. Am. Ass. Adwnt. Sci., (83):3-5.

(Manuscript received 01 August 1996; revised 31 October 1996; accepted 26 December 1996) 